\title{
Xylanase and $\beta$-glucanase in maize- and soybean meal-based diets for broilers
}

\section{Xilanase e $\beta$-glucanase em dietas a base de milho e de farelo de soja para frangos de corte}

\author{
Thiago Ferreira Diana ${ }^{1 *}$; Luiz Fernando Teixeira Albino ${ }^{2}$; Horácio Santiago \\ Rostagno $^{2}$; Bruno Figueiredo de Almeida ${ }^{3}$; Maurílio de Lucas Xavier Júnior ${ }^{1}$; \\ Pedro Eleutério Aleixo ${ }^{4}$; Samuel Oliveira Borges ${ }^{3}$; Arele Arlindo Calderano ${ }^{2}$
}

\section{Highlights:}

Interaction between energy and amino acid levels and use of different enzyme blends.

Xylanase and $\beta$-glucanase improve production efficiency index in broilers.

Exogenous enzymes improve the metabolizable energy of diets in broilers.

\begin{abstract}
The objective of this study was to evaluate the effect of adding different xylanase and $\beta$-glucanase enzyme blends to maize- and soybean meal-based diets on performance and energy metabolizability in broilers. Two experiments were carried out with broilers of the COBB 500 strain. In the first experiment, 1960 chicks were assigned to a completely randomized design with a $2 \times 3+1$ factorial arrangement, totaling seven treatments, namely, T1- Positive control (PC); T2 - Negative control 1 (NC1; PC minus $200 \mathrm{kcal} \mathrm{kg}^{-1} \mathrm{ME}$ ); T3 - NC1 + Blend A; T4 - NC1 + Blend B; T5 - Negative control 2 (NC2; PC minus $167 \mathrm{kcal} \mathrm{kg}^{-1} \mathrm{ME}$ and 5\% amino acids); $\mathrm{T} 6$ - NC2 + Blend A; and T7 - NC2 + Blend B. Fourteen replicates were used per treatment and 20 birds per experimental unit. The parameters evaluated at 21 and 42 days of age were weight gain (WG), feed intake (FI) and feed conversion (FC). At 42 days, production efficiency index (PEI), viability and the yields of cuts were also calculated. Birds that received diets with a reduced nutritional value showed a reduction in WG and PEI and worsened FC as compared those of PC treatment $(p<0.05)$. However, the birds that consumed the NC2 diet with Blend $\mathrm{B}$ exhibited a similar WG to those in PC group $(\mathrm{p}>0.05)$ from 1 to 21 days of life. For the yield of thigh + drumstick, the factors were statistically similar $(p>0.05)$ to those observed in the PC birds. In the second experiment, 432 fourteen-day-old chicks were distributed in a completely randomized design with seven treatments, with eight replicates per treatment and six birds per experimental unit. The apparent metabolizable energy (AME) and nitrogen-corrected AME (AMEn) values were determined. Overall, the NC2 diet with Blend B provided the highest AME and AMEn values; however, NC1 with the same enzyme blend was the treatment which provided the lowest values. The addition of xylanase and $\beta$-glucanase enzyme blends to maize- and soybean meal-based diets improves WG at 21 days as well as PEI in broilers; however, it does not influence the yield of cuts. Enzymes (Blend B) improve the energy metabolization of broiler diets with reduced energy and amino acid levels.
\end{abstract}

Key words: Antinutritional factors. Exogenous enzymes. Metabolizable energy. NSPs.

\footnotetext{
${ }^{1}$ Discentes do Curso de Doutorado do Programa de Pós-Graduação em Zootecnia, Departamento de Zootecnia, Universidade Federal de Viçosa, UFV, Viçosa, MG, Brasil. E-mail: thiagofnet@hotmail.com; maurilio junior1@hotmail.com

2 Profs., Departamento de Zootecnia, UFV, Viçosa, MG, Brasil. E-mail: lalbino@ufv.br; rostagno@ufv.br; calderano@ufv.br

3 Discentes do Curso de Graduação em Zootecnia, Departamento de Zootecnia, UFV, Viçosa, MG, Brasil. E-mail: brunofa.zoo@ gmail.com; samuelborges1001@gmail.com

4 Discente do Curso de Mestrado do Programa de Pós-Graduação em Zootecnia, Departamento de Zootecnia, UFV, Viçosa, MG, Brasil.E-mail: pealeixomv@gmail.com

* Author for correspondence
} 


\section{Resumo}

Objetivou-se avaliar o efeito da adição de diferentes blends enzimáticos de xilanase e $\beta$-glucanase em dietas a base de milho e de farelo de soja sobre o desempenho e metabolizabilidade da energia para frangos de corte. Foram realizados dois experimentos com frangos de corte da linhagem COBB 500. No primeiro experimento, foram utilizados 1960 pintos distribuídos em delineamento inteiramente casualizado em arranjo fatorial $2 \times 3+1$, totalizando sete tratamentos: T1- Controle Positivo (CP); T2 - Controle negativo 1 (CN1; CP menos $200 \mathrm{kcal} \mathrm{Kg}^{-1}$ de EM); T3 - CN1 + Blend A; T4 - CN1 + Blend B; T5 - Controle negativo 2 (CN2; CP menos $167 \mathrm{kcal} \mathrm{Kg}^{-1}$ de EM e 5\% de aminoácidos); T6 - CN2 + Blend A e T7 - CN2 + Blend B. Foram utilizadas 14 repetições por tratamento e 20 aves por unidade experimental. Os parâmetros avaliados aos 21 e aos 42 dias de idade dos frangos foram o ganho de peso (GP), o consumo de ração (CR) e a conversão alimentar (CA). Aos 42 dias calculou-se o índice de eficiência produtiva (IEP), viabilidade (VIAB) e rendimento de cortes. Foi observado que as aves que receberam dietas com reduzido valor nutricionais apresentaram redução no GP e IEP e piora na CA comparadas ao CP $(\mathrm{p}<0,05)$, porém as aves que consumiram a dieta $\mathrm{CN} 2$ com o Blend $\mathrm{B}$, que apresentaram GP semelhante ao CP $(\mathrm{p}>0,05)$ no período de um a 21 dias de vida. Para o rendimento de coxa mais sobrecoxa (RCS), foi possível observar que os fatores apresentaram estatisticamente ( $p>$ $0,05)$ semelhantes ao CP. No segundo experimento foram utilizados 432 pintos com 14 dias de idade, distribuídas em um delineamento inteiramente casualizado com sete tratamentos com 8 repetições por tratamento e 6 aves por unidade experimental. Foram determinados os valores de energia metabolizável aparente (EMA) e aparente corrigida para balanço de nitrogênio (EMAn). Em geral, a dieta CN2 com o Blend B apresentou o maior valor de EMA e EMAn, porém, o CN1 com o mesmo Blend enzimático foi o que apresentou os menores valores. A adição de blends enzimáticos de xilanase e $\beta$-glucanase em dietas a base de milho e de farelo de soja melhora o GP aos 21 dias, bem como o IEP de frangos de corte, porém, não influencia o rendimento de cortes. As enzimas (Blend B) melhora metabolizabilidade da energia de dietas com redução dos níveis de energia e aminoácidos para frangos de corte.

Palavras-chave: Enzimas exógenas. Energia metabolizável. Fatores antinutricionais. PNA’s.

\section{Introduction}

The use of exogenous enzymes has been investigated in animal nutrition due to their ability to improve the use of low-digestible ingredients (Barbosa et al., 2014); reduce nutrients losses through excretion as well as environmental pollution (Leite et al., 2011); and improve performance and carcass characteristics in broilers (Dalólio et al., 2016).

Exogenous carbohydrases help break down plant cell-wall structures and their content, such as starch, fats and proteins. These then become exposed, facilitating the access of endogenous proteases of birds (Silva el al., 2016). In this way, in addition to contributing to a greater use of amino acids (Cowieson \& Ravindran, 2008; Cowieson, 2010), diets containing exogenous carbohydrases ( $\alpha$-amylase, $\boldsymbol{\beta}$-glucanase and xylanase) also contribute to the utilization of the indigestible fraction, which is favored by the action of glucanase and xylanase, reaching $27 \%$ and $20 \%$, respectively (Cowieson, 2010; Silva et al., 2016).

Despite the low indigestible content of maize (Rostagno et al., 2017), this ingredient contains non-starch polysaccharide (NSP) fractions, and the use of enzyme blends can contribute to increasing the digestibility of nutrients and metabolizable energy (Aguilar, Delgado, Bueno, \& RodríguezLeón, 2007). Additionally, it helps to reduce antinutritional factors in soybean meal (Cowieson, 2005). However, there are few literature reports confirming the benefits of using exogenous enzymes in maize- and soybean meal-based diets for broilers.

Therefore, this study was developed to examine the effect of adding different xylanase and $\beta$-glucanase enzyme blends to maize- and soybean meal-based diets on performance and energy metabolizability in broilers. 


\section{Material and Methods}

The research was previously authorized by the ethics committee on the use of farm animals at the Federal University of Viçosa, (approval no. 21/2019) and is in agreement with the ethical principles of animal experimentation.

\section{Experiment 1}

A total of 1960 one-day-old male broiler chicks of the COBB 500 strain were used. The birds were allotted to a completely randomized design with a $2 \times 3+1$ factorial arrangement, totaling seven treatments, namely, T1- Positive Control (PC); T2 - Negative control 1 (NC1; PC minus $200 \mathrm{kcal} \mathrm{kg}^{-1}$
$\mathrm{ME}) ; \mathrm{T} 3$ - NC1 + Blend A; T4 - NC1 + Blend B; T5 - Negative control 2 (NC2; PC minus $167 \mathrm{kcal}$ $\mathrm{kg}^{-1} \mathrm{ME}$ and 5\% amino acids); $\mathrm{T} 6$ - NC2 + Blend A; and $\mathrm{T} 7-\mathrm{NC} 2+$ Blend B. Fourteen replicates were used per treatment and the experimental unit was represented by 20 birds.

The diets were maize- and soybean meal-based and formulated following the recommendations proposed by Rostagno et al. (2017) for each experimental phase (Tables 1 and 2). The different exogenous-enzyme blends used were based on carbohydrases $(\beta$-xylanase $+\beta$-glucanase $)$ and were added to the diets replacing starch $\left(500 \mathrm{~g} \mathrm{t}^{-1}\right)$, according to the manufacturer's recommendations. 


\section{Table 1}

Percentage composition and estimated nutritional value of the experimental treatments: positive (PC) and negative (NC1 and NC2) control diets for broilers from 1 to 21 days of age

\begin{tabular}{|c|c|c|c|}
\hline Ingredient & PC & NC1 & $\mathrm{NC2}$ \\
\hline Maize $7.9 \%$ & 49,282 & 53,980 & 57,044 \\
\hline Soybean meal 45\% & 41,862 & 40,990 & 37,912 \\
\hline Soybean oil & 5,348 & 1,500 & 1,500 \\
\hline Dicalcium phosphate & 0,975 & 0,968 & 0,990 \\
\hline Limestone & 1,050 & 1,059 & 1,072 \\
\hline Common salt & 0,515 & 0,514 & 0,514 \\
\hline DL-methionine $99 \%$ & 0,317 & 0,312 & 0,293 \\
\hline L-lysine $54,6 \%$ & 0,124 & 0,140 & 0,153 \\
\hline L-threonine $98 \%$ & 0,045 & 0,044 & 0,040 \\
\hline Mineral supplement ${ }^{1}$ & 0,130 & 0,130 & 0,130 \\
\hline Vitamin supplement ${ }^{2}$ & 0,130 & 0,130 & 0,130 \\
\hline Choline chloride $60 \%$ & 0,100 & 0,100 & 0,100 \\
\hline Salinomycin 12\% (Cocxistac) & 0,055 & 0,055 & 0,055 \\
\hline Antioxidant BHT & 0,001 & 0,001 & 0,001 \\
\hline Phytase enzyme 10000 FTU & 0,005 & 0,005 & 0,005 \\
\hline Starch* & 0,050 & 0,050 & 0,050 \\
\hline Total & 100,000 & 100,000 & 100,000 \\
\hline \multicolumn{4}{|l|}{ Calculated values } \\
\hline Crude protein, $\%$ & 23,30 & 23,30 & 22,153 \\
\hline Metabolizable energy, $\mathrm{kcal} / \mathrm{kg}$ & 3150 & 2950 & 2983 \\
\hline Calcium, $\%$ & 0,937 & 0,937 & 0,937 \\
\hline Available phosphorus, $\%$ & 0,440 & 0,440 & 0,440 \\
\hline Sodium, $\%$ & 0,218 & 0,218 & 0,218 \\
\hline Digestible lysine, $\%$ & 1,256 & 1,256 & 1,193 \\
\hline Digestible methionine + cystine, $\%$ & 0,929 & 0,929 & 0,883 \\
\hline Digestible threonine, $\%$ & 0,829 & 0,829 & 0,787 \\
\hline Digestible tryptophan, \% & 0,268 & 0,267 & 0,277 \\
\hline Digestible valine, $\%$ & 0,972 & 0,969 & 0,919 \\
\hline Digestible arginine, $\%$ & 1,469 & 1,459 & 1,373 \\
\hline Digestible glycine + serine, $\%$ & 1,880 & 1,874 & 1,775 \\
\hline
\end{tabular}

*Inert.

${ }^{1}$ Mineral supplement (provides per of diet): manganese - $77 \mathrm{mg}$; iron - $55.0 \mathrm{mg}$; zinc - $71.5 \mathrm{mg}$; copper - $11.0 \mathrm{mg}$; iodine - 1.10 mg; cobalt $-2.0 \mathrm{~g}$.

${ }^{2}$ Vitamin supplement (provides per of diet): vitamin A - $8250 \mathrm{IU}$; vitamin D3 - $2090 \mathrm{IU}$; vitamin E - $31 \mathrm{IU}$; vitamin B1 - 2.2 mg; vitamin B2 - $5.5 \mathrm{mg}$; vitamin B6 - $3.08 \mathrm{mg}$; pantothenic acid - $11.0 \mathrm{mg}$; biotin - $0.077 \mathrm{mg}$; vitamin K3 - $1.65 \mathrm{mg}$; folic acid - 0.77 $\mathrm{mg}$; nicotinic acid- $33.0 \mathrm{mg}$; vitamin B12 - $0.013 \mathrm{mg}$; selenium - $0.330 \mathrm{mg}$. 
Table 2

Percentage composition and estimated nutritional value of the experimental treatments: positive (PC) and negative (NC1 and NC2) control diets for broilers from 21 to 42 days of age

\begin{tabular}{|c|c|c|c|}
\hline Ingredient & PC & NC1 & NC2 \\
\hline Maize $7.9 \%$ & 56.414 & 61.140 & 63.756 \\
\hline Soybean meal $45 \%$ & 35.245 & 34.482 & 31.854 \\
\hline Soybean oil & 5.468 & 1.500 & 1.500 \\
\hline Dicalcium phosphate & 0.663 & 0.655 & 0.673 \\
\hline Limestone & 0.834 & 0.844 & 0.854 \\
\hline Common salt & 0.492 & 0.491 & 0.492 \\
\hline DL-methionine $99 \%$ & 0.273 & 0.267 & 0.247 \\
\hline Biolis $^{3} 54.6 \%$ & 0.218 & 0.237 & 0.247 \\
\hline L-threonine $98 \%$ & 0.038 & 0.036 & 0.031 \\
\hline Mineral supplement ${ }^{1}$ & 0.100 & 0.100 & 0.100 \\
\hline Vitamin supplement ${ }^{2}$ & 0.100 & 0.100 & 0.100 \\
\hline Choline chloride $60 \%$ & 0.100 & 0.100 & 0.100 \\
\hline Salinomycin $12 \%$ (Cocxistac) & 0.055 & 0.055 & 0.055 \\
\hline Antioxidant BHT & 0.010 & 0.001 & 0.001 \\
\hline Phytase enzyme 10000 FTU & 0.005 & 0.005 & 0.005 \\
\hline Starch* & 0.050 & 0.050 & 0.050 \\
\hline Total & 100.000 & 100.000 & 100.000 \\
\hline \multicolumn{4}{|l|}{ Calculated values } \\
\hline Crude protein, $\%$ & 20.879 & 20.920 & 19.929 \\
\hline Metabolizable energy, $\mathrm{kcal} / \mathrm{kg}$ & 3250 & 3043 & 3071 \\
\hline Calcium, \% & 0.758 & 0.937 & 0.758 \\
\hline Available phosphorus, $\%$ & 0.374 & 0.374 & 0.374 \\
\hline Sodium, $\%$ & 0.208 & 0.218 & 0.208 \\
\hline Digestible lysine, $\%$ & 1.124 & 1.124 & 1.068 \\
\hline Digestible methionine + cystine, $\%$ & 0.832 & 0.832 & 0.790 \\
\hline Digestible threonine, $\%$ & 0.742 & 0.742 & 0.705 \\
\hline Digestible tryptophan, $\%$ & 0.235 & 0.234 & 0.220 \\
\hline Digestible valine, $\%$ & 0.865 & 0.865 & 0.822 \\
\hline Digestible arginine, $\%$ & 1.381 & 1.459 & 1.207 \\
\hline Digestible glycine + serine, $\%$ & 1.669 & 1.668 & 1.618 \\
\hline
\end{tabular}

*Inert.

${ }^{1}$ Mineral supplement (provides per of diet): manganese - $77 \mathrm{mg}$; iron - $55.0 \mathrm{mg}$; zinc - $71.5 \mathrm{mg}$; copper - $11.0 \mathrm{mg}$; iodine - 1.10 mg; cobalt $-2.0 \mathrm{~g}$.

${ }^{2}$ Vitamin supplement (provides per of diet): vitamin A - 8250 IU; vitamin D3 - 2090 IU; vitamin E - 31 IU; vitamin B1 - 2.2 mg; vitamin B2 - $5.5 \mathrm{mg}$; vitamin B6 - $3.08 \mathrm{mg}$; pantothenic acid - $11.0 \mathrm{mg}$; biotin - $0.077 \mathrm{mg}$; vitamin $\mathrm{K} 3$ - $1.65 \mathrm{mg}$; folic acid - 0.77 $\mathrm{mg}$; nicotinic acid- $33.0 \mathrm{mg}$; vitamin B12 - $0.013 \mathrm{mg}$; selenium - $0.330 \mathrm{mg}$.

${ }^{3}$ L-lysine $54.6 \%$. 
Enzyme complex A (Blend A) originates from the fermentation process of two genetically modified strains of Aspergillus niger, containing endo-1,4beta-xylanase and endo-1,4-beta-glucanase, at the recommended activity levels of 560 TXU and 250 TGU per kg of feed. Complex B (Blend B) is the preparation of endo-1,3(4)-beta-glucanase and endo-1,4-beta-xylanase, which were produced by a non-genetically modified strain of Penicillium funiculosum. These two forms ensure at least 30,000 viscosimetric U or 4300 DNS U glucanase and 22,000 viscosimetric U or 3200 DNS U xylanase per gram.

Birds were raised in cages $(2 \mathrm{~m}$ wide $\times 2 \mathrm{~m}$ long $\times 0.50 \mathrm{~m}$ high) at the density of five chicks per square meter. The cement floor was covered with a 10-cm-thick wood shavings litter. Pressure-cup drinkers and tray feeders were used in the first 10 days. Thereafter, these were replaced with nipple drinkers and trough feeders, respectively, which remained until the end of the experiment. The average maximum and minimum temperatures in the phases from 1 to 21 days and 1 to 42 days were 28.6 and $21.3^{\circ} \mathrm{C}$ and 26.1 and $20.1^{\circ} \mathrm{C}$, respectively.

The following performance variables were evaluated at 21 and 42 days: feed intake (FI), weight gain (WG), feed conversion (FC), viability and productive efficiency index (PEI).

At 42 days of age, two birds from each experimental unit were slaughtered to measure the yields of breast (BY) and drumstick + thigh (DTY).

Data were subjected to ANOVA and means were compared by Tukey's test at $5 \%$ probability. To test the significance of the factors and the interaction between them and the additional treatment, the values were subjected to Dunnett's test. The R core team [R] (2019) statistical package was used.

\section{Experiment II}

This experiment involved 432 male broiler chicks of the COBB 500 strain at 14 days of age.
From birth to 14 days old, the birds were raised in a brick shed $(3.0 \times 3.0 \mathrm{~m}$, with a density of 500 chicks), with floors covered with wood shavings, where they received adequate feed for the starter phase following the recommendations of Rostagno et al. (2017). The average maximum and minimum temperatures were 27.8 and $19.0^{\circ} \mathrm{C}$, respectively.

At 14 days of age, the birds were transferred to metal batteries $(0.50 \mathrm{~m}$ wide $\times 0.50 \mathrm{~m}$ long $\times 0.40 \mathrm{~m}$ high). The animals were distributed in a completely randomized design with seven treatments, namely, T1- Positive control (PC); T2 - Negative control 1 (NC1; PC minus $200 \mathrm{kcal} \mathrm{kg}^{-1} \mathrm{ME}$ ); $\mathrm{T} 3-\mathrm{NC1}+$ Blend A; T4 - NC1 + Blend B; T5 - Negative control 2 (NC2; PC minus $167 \mathrm{kcal} \mathrm{kg}^{-1} \mathrm{ME}$ and 5\% amino acids); $\mathrm{T} 6$ - NC2 + Blend $\mathrm{A}$; and $\mathrm{T} 7$ - NC2 + Blend B. Eight replicates were used per treatment and six birds per experimental unit.

The diets were provided ad libitum for a period of 10 days, which consisted of five days of adaptation and five days for excreta collection by the total collection methodology (Sakomura \& Rostagno, 2016). Fecal collections were carried out twice daily, at $08 \mathrm{~h} 00$ and at $16 \mathrm{~h} 00$, to avoid fermentation and nutrient losses.

The excreta collected from each experimental unit were placed in labeled plastic bags, which were then stored in a freezer $\left(-18^{\circ} \mathrm{C}\right)$ until the end of the collection period. At the end of the experimental period, the collected excreta were thawed, weighed, homogenized and dried in a forced-air oven at $55^{\circ}$ $\mathrm{C}$ for $72 \mathrm{~h}$.

Nitrogen $(\mathrm{N})$, dry matter (DM) and gross energy (GE) contents of diets and excreta were determined. These data were used to determine the apparent metabolizable energy (AME) and nitrogen-corrected AME (AMEn) values of the samples, following the methodology proposed by Sakomura and Rostagno (2016). 
The following equations were used for the calculations of AME and AMEn:

$$
\begin{aligned}
& \mathrm{AME}_{\mathrm{D}}=\frac{\mathrm{GE}_{\underline{\mathrm{int}}}-\mathrm{GE}_{\mathrm{exc}}}{\mathrm{DM}_{\mathrm{int}}} \\
& \mathrm{AMEn}_{\mathrm{D}}=\left(\underline{\mathrm{GE}}_{\underline{\mathrm{int}}}-\frac{\mathrm{GE}_{\mathrm{exc}}}{\underline{\mathrm{DM}_{\mathrm{int}}}-8.22 \times \mathrm{NB}}\right. \\
& \mathrm{NB}=\mathrm{N}_{\mathrm{int}}-\mathrm{N}_{\mathrm{exc}}
\end{aligned}
$$

where $\mathrm{AME}_{\mathrm{D}}=$ apparent metabolizable energy of the diet; $\mathrm{AMEn}_{\mathrm{D}}=$ nitrogen-corrected apparent metabolizable energy of the diet; $\mathrm{N}_{\text {int }}=$ nitrogen intake; $\mathrm{N}_{\mathrm{exc}}=$ nitrogen excretion; $\mathrm{NB}=$ nitrogen balance; $\mathrm{GE}_{\text {int }}=$ gross energy inteke; and $\mathrm{GE}_{\mathrm{exc}}=$ gross energy excretion.

Data were subjected to ANOVA and means were evaluated by Tukey's test at 5\% probability using the statistical package of SAS (Statistical Analysis System Institute [SAS Institute], 2009) software.

\section{Results and Discussion}

There was no significant interaction effect $(\mathrm{p}>$ 0.05 ) between the $\mathrm{NC} 1$ and $\mathrm{NC} 2$ diets and the use of enzyme complex for any of the variables studied from 1 to 21 days (Table 3) or 1 to 42 days (Table 4 ) of age. There was also no interaction effect ( $p>$ 0.05 ) between PC diet and the diets with or without the use of enzyme blends for FI in either studied period. Due to their reduced ME and/or amino acid levels, the diets with or without enzymes were expect to promote changes in FI. According to Dessimoni et al. (2019), birds tend to increase their FI in an attempt to compensate for the nutrient deficit. As stated by Gopinger, Krabbe, Surek, Lopes and Avila (2017), FI in broilers is increased with a reduction in the dietary DM. The reduction in energy and amino acid levels in the present study was possibly not severe enough to prompt an adjustment in FI.

An interaction effect $(p<0.05)$ between PC and the diets with or without enzyme complex was observed for WG and FC in the periods of 1 to 21 days and 1 to 42 days of age, as well as for PEI from 1 to 42 days old. By decomposing the interactions, we observed that the birds that received diets with a reduced nutritional value showed a reduction in WG and PEI and worsened FC as compared with the animals fed PC $(p<0.05)$. However, the birds that consumed the NC2 diet with Blend B showed a similar WG to those fed PC $(p>0.05)$ in the period from 1 to 21 days of life. Thus, enzyme complex B was likely effective in providing better nutrient availability for the birds. González-Ortiz, Olukosi and Bedford (2016) and Liu and Kim (2017) attributed the improvement in performance with the use of exogenous carbohydrases to the reduced viscosity of the digesta and improved nutrient digestibility. However, Olukosi, Cowieson and Adeola (2008) reported that supplementation with a multi-enzyme complex (xylanase, amylase and protease) in maize-, soybean meal- and wheatbased diets did not improve WG or feed efficiency in broilers. This divergence of results can be partly explained by differences in enzyme species and in the concentrations of each compound enzyme, diet formulations and animal characteristics (Lei et al., 2017). 


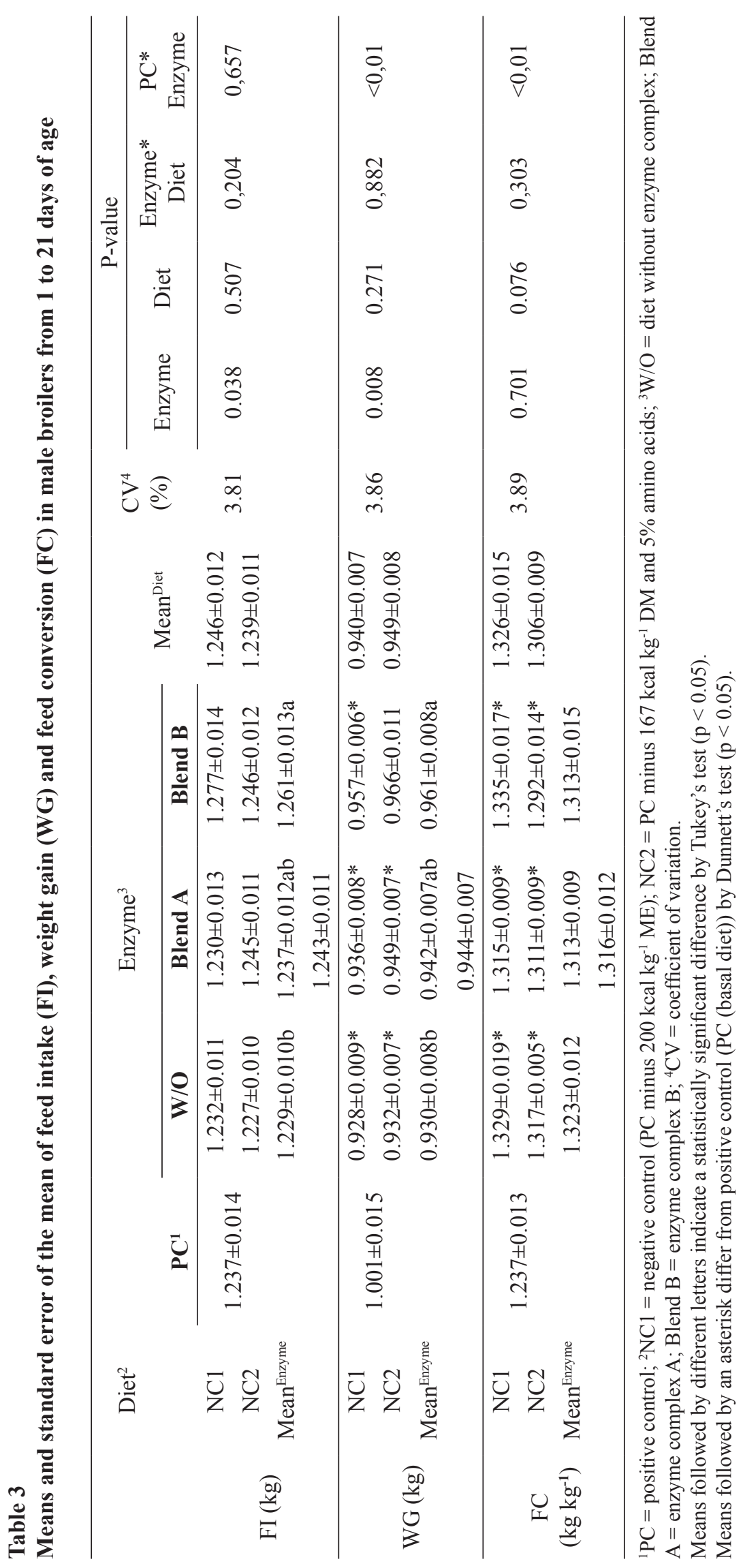




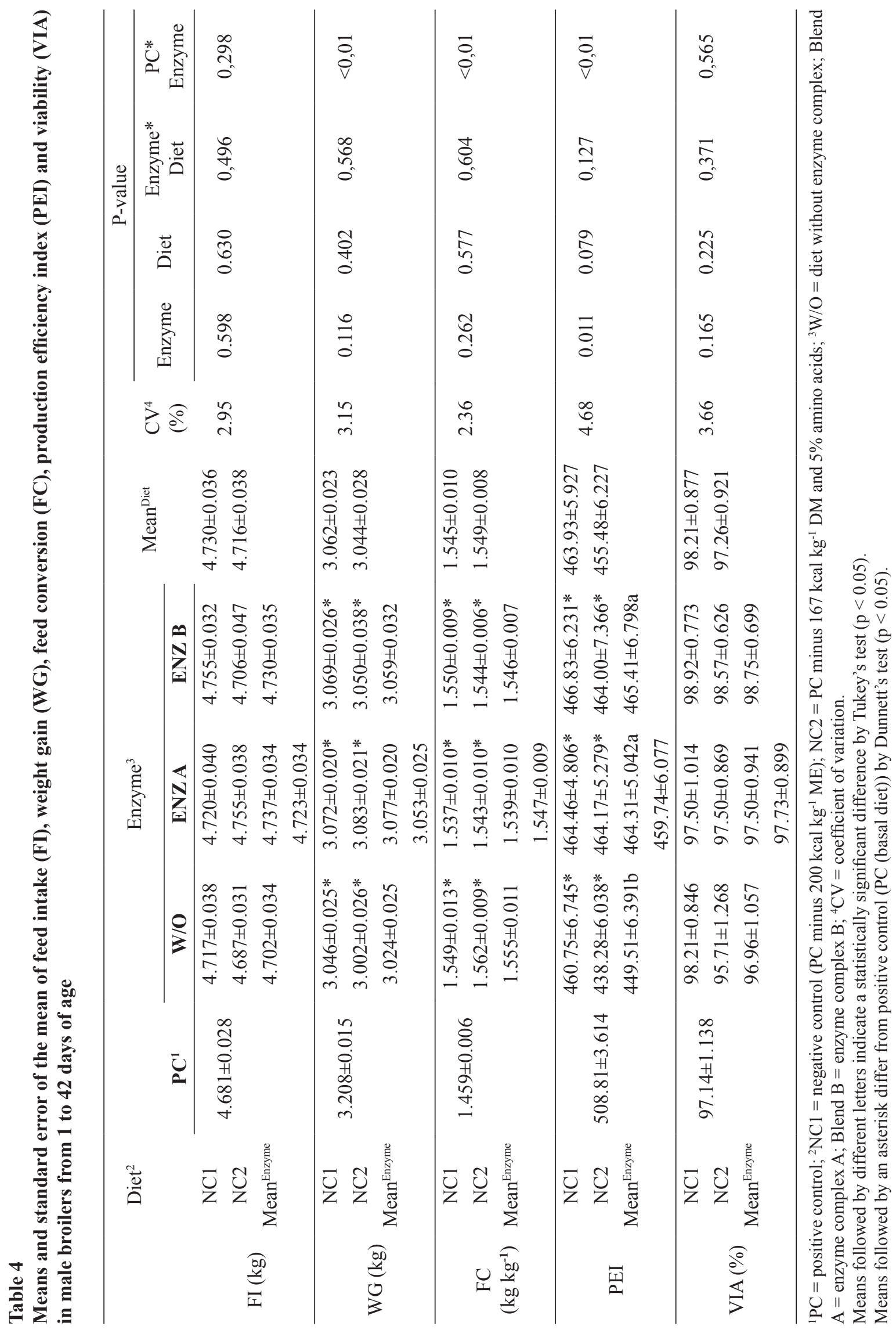


In the period from 1 to 21 days of age, the birds that received Blend B showed higher FI and WG than the group treated without enzymes ( $p<$ $0.05)$. Although maize and soybean meal are highly digestible feedstuffs, exogenous enzymes can improve their nutritional value (Zanella, Sakomura, Silversides, Fiqueirdo, \& Pack, 1999). This improvement may be linked to the specific action of the enzymes. Xylanase hydrolyzes the cell wall of maize arabinoxylans and reduces antinutritional factors in some polysaccharides of soybean meal. As a result, the access to cell content by endogenous enzymes is increased (Kocher, Choct, Ross, Broz, \& Chung, 2003; Meng, Slominski, Nyachoti, Campbell, \& Guenter, 2005; Francesch \& Geraert, 2009). The introduction of exogenous enzymes in chick feed after hatching also favors the appearance of beneficial intestinal microbiota, promoting recovery of nutrients and greater resistance to possible digestive disorders. The diets with multienzyme complexes also promoted higher PEI ( $p$ $<0.05)$ as compared with the treatment without enzyme addition. Zanella et al. (1999) found no differences between the treatments with reduced nutrient levels and enzymes and the treatment with adequate nutrient levels without enzymes for PEI, which confirms the efficiency of the enzymes, as also observed in this study. When grouped in a single index, the statistical and numerical differences observed in the performance variables also indicate the benefits of enzyme inclusion. However, there was no effect of enzyme addition on FC ( $p>0.05)$. This result corroborates those observed by Garcia, Murakami, Branco, Furlan and Moreira (2000), Fischer, Maier, Rutz, and Bermudez (2002) and Souza et al. (2008), who also supplemented maizeand soybean meal-based diets with enzymes.

Despite the positive effects observed in the present study, disagreeing results have been published by other authors. West, Corzo, Dozierlii, Blair and Kidd (2007) did not observe an effect of the xylanase- $\beta$-glucanase complex on the performance of broilers fed maize- and soybean meal-based diets, possibly because the levels of nutrients in the formulated treatments were close to the ME requirement of the birds. According to Munyaka, Nandha, Kiarie, Nyachoti and Khafipour (2016), ingredients with a high digestibility rate, such as maize and soybean meal, exhibited a lesser effect of the action of exogenous carbohydrates when compared with feedstuffs such as barley, wheat and rye. The lack of significant effects on performance demonstrated in some studies can be explained by the low NSP content of maize- and soybean meal-based diets. The activity of enzymes is directly related to the type of substrate contained in the gastrointestinal tract of birds (Woyengo \& Nyachoti, 2011; Meneghetti, 2013; Dessimoni et al., 2019).

No interaction effect $(p>0.05)$ was observed between diets $\mathrm{NC} 1$ and $\mathrm{NC} 2$ and the use of enzyme complex for the yields of cuts (Table 5).

Unlike BY, which did not change ( $\mathrm{p}>0.05)$, DTY differed $(p<0.05)$ in response to the interaction between PC and the diets with or without enzyme. By decomposing the interaction, it is observed that regardless of the diets with reduced nutritional value and enzyme, the yield results were statistically similar $(p>0.05)$ to those of the PC group. Santos, O’Neill, González-Ortiz, Camacho-Fernández and López-Coello (2017) investigated the interaction of xylanase, protease and an overdose of phytase on performance, carcass yield, bone ash content and digesta transit time in broilers fed sorghumbased diets and did not observe an interaction effect between the enzymes, but favorable results for carcass yield with the inclusion of xylanase. According to Oba et al. (2012), BY and DTY are inversely proportional, that is, when a treatment increases the yield of breast, the drumstick + thigh set will have a lower yield. The breast has glycolytic metabolism and its substrate is glucose, whereas the metabolism of drumstick + thigh is oxidative, whose substrate are fatty acids (Baziz, Geraert, Padilha, \& Guillaumin, 1996). The substrate most readily used by birds is glucose or its reserve in the form of 
glycogen, and hence the greater muscle deposition. However, if the animals suffer some heat stress, for instance, panting and glycogen intake will increase due to greater muscle activity, which contributes to a lower BY and a greater DTY (Temim et al., 2000; Oba et al., 2012).

There was no significant effect $(p>0.05)$ of use or non-use of enzyme and diet types ( $\mathrm{NC1}$ and NC2) for BY and DTY. These results corroborate those found by Cardoso et al. (2011) and Fortes et al. (2012), who also described no significant effects for these parameters.

A significant effect $(p<0.01)$ was observed for AME and AMEn (Table 6). Overall, the NC2 diet with Blend $\mathrm{B}$ provided the highest AME and AMEn values; however, NC1 with the same enzyme blend resulted in the lowest values. These results can be explained by the metabolization of amino acids, since, according to Noblet, Henry and
Dubois (1987) and Roth, Gotterbarm, Windisch and Kirchgessner (1999), reduced protein and/or amino acids levels in the diet have been associated with decreased energy losses. Accordingly, the 5\% amino acid reduction in NC2 may have contributed to the lower deamination and caloric increase in the birds. Furthermore, according to these authors, diets with reduced amino acids can lead to improved use of energy for tissue deposition. Moura et al. (2019) examined the effect of enzyme complexes on the metabolizable energy and digestibility coefficient of nutrients from millet for broilers from 11 to 21 days of age and observed a reduction in the AME and AMEn values of diets containing enzyme complex (protease, cellulase and amylase enzymes). The same authors also found a reduction in AME and AMEn in diets with the addition of enzyme complexes (phytase, protease, xylanase, $\beta$-glucanase, cellulase, amylase and pectinase enzymes) for broilers aged 31 to 40 days. 


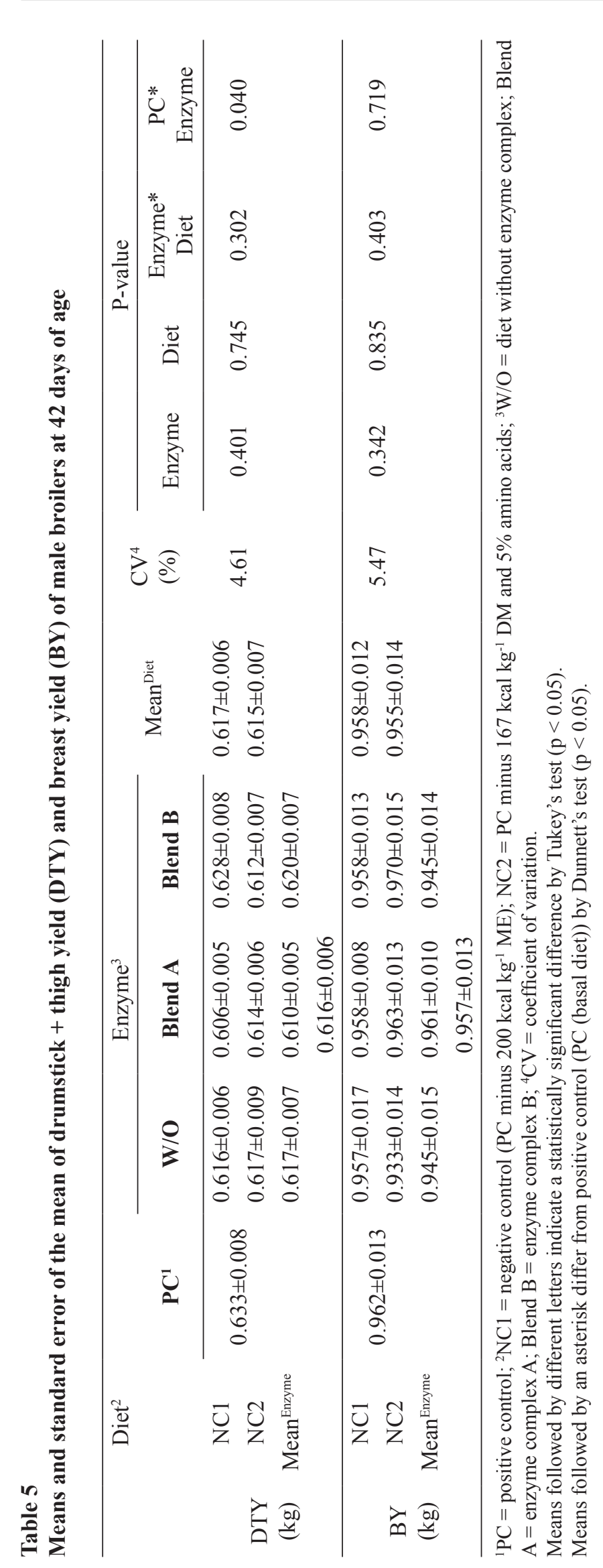


Table 6

Apparent metabolizable energy (AME) and nitrogen-corrected AME (AMEn) values of the experimental diets for broilers

\begin{tabular}{|c|c|c|}
\hline \multirow{2}{*}{ Treatment $^{1}$} & AME & AMEn \\
\hline & Kcal kg-1 & Kcal kg-1 \\
\hline $\mathrm{PC}$ & $2919.54 \mathrm{ab}$ & $2877.25 \mathrm{ab}$ \\
\hline $\mathrm{NC1}(\mathrm{W} / \mathrm{O})$ & $2913.71 \mathrm{ab}$ & $2857.44 \mathrm{ab}$ \\
\hline $\mathrm{NC} 1\left(\mathrm{Blend}^{3} \mathrm{~A}\right)$ & $2845.85 b c$ & $2793.61 b c$ \\
\hline NC1 (Blend B) & $2742.85 \mathrm{c}$ & $2707.87 \mathrm{c}$ \\
\hline NC2 (W/O) & $2855.53 b$ & $2789.78 b c$ \\
\hline NC2 (Blend A) & $2812.57 b c$ & $2768.11 b c$ \\
\hline NC2 (Blend B) & $2975.17 \mathrm{a}$ & $2939.37 \mathrm{a}$ \\
\hline $\mathrm{CV}^{2}$ & 2.36 & 2.29 \\
\hline P-value & $<.0001$ & $<.0001$ \\
\hline
\end{tabular}

${ }^{1} \mathrm{PC}=$ positive control; $\mathrm{NC} 1(\mathrm{~W} / \mathrm{O})=$ negative control $\left(\mathrm{PC}\right.$ minus $\left.200 \mathrm{kcal} \mathrm{kg}{ }^{-1} \mathrm{ME}\right) ; \mathrm{NC} 1(\mathrm{Blend} \mathrm{A})=\mathrm{NC} 1+\mathrm{Blend} \mathrm{A} ; \mathrm{NC} 1(\mathrm{Blend}$ $\mathrm{B})=\mathrm{NC} 1+\mathrm{Blend} \mathrm{B} ; \mathrm{NC} 2(\mathrm{~W} / \mathrm{O})=\mathrm{PC}$ minus $167 \mathrm{kcal} \mathrm{kg}^{-1} \mathrm{ME}$ and 5\% amino acids; $\mathrm{NC} 2(\mathrm{Blend} \mathrm{A})=\mathrm{NC} 2+\mathrm{Blend} \mathrm{A} ; \mathrm{NC} 2$ $(\mathrm{Blend} \mathrm{B})=\mathrm{NC} 2+\mathrm{Blend} \mathrm{B} ;{ }^{2} \mathrm{CV}=$ coefficient of variation. ${ }^{3} \mathrm{Blend}=$ enzyme complex (xylanase and $\beta$-glucanase).

Means followed by different letters in the column indicate a statistically significant difference by Tukey's test $(p<0.05)$.

\section{Conclusions}

The addition of xylanase and $\beta$-glucanase enzyme blends to maize- and soybean meal-based diets improves weight gain at 21 days as well as the production efficiency index of broilers, but does not influence the yields of carcass cuts.

The enzymes (Blend B) improve the energy metabolization of broiler diets with reduced energy and amino acid levels.

\section{Acknowledgments}

This study was supported by the Coordination for the Improvement of Higher Education Personnel - Brazil (CAPES).

\section{References}

Aguilar, L., Delgado, G., Bueno, G., \& Rodríguez-León, J. A. (2007). Enzyme application in animal feeding: requirements and perspectives. Revista Cubana de Ciencia Avícola, 31(1), 45-55.
Barbosa, N. A. A., Bonato, M. A., Sakomura, N. K., Dourado, L. R. B., Fernandes, J. B. K., \& Kawauchi, I. M. (2014). Digestibilidade ileal de frangos de corte alimentados com dietas suplementadas com enzimas exógenas. Comunicata Scientiae, 5(4), 361-369. doi: 10.14295/cs.v5i4.460

Baziz, H. A., Geraert, P. A., Padilha, J. C. F., \& Guillaumin, S. (1996). Chronic heat exposure enhances fat deposition and modifies muscle and fat partition in broiler carcasses. Poultry Science, 75(4), 505-513. doi: 10.3382/ps.0750505

Cardoso, D. M., Maciel, M. P., Passos, D. P., Silva, F. V., Reis, S. T., \& Aiura, F. S. (2011). Efeito do uso de complexo enzimático em rações para frangos de corte. Archivos de Zootecnia, 60(232), 1053-1064. doi: 10.4321/S0004-05922011000400021

Cowieson, A. J. (2005). Factors that affect the nutritional value of maize for broilers. Animal Feed Science and Technology, 119(3-4), 293-305. doi: 10.1016/j. anifeedsci.2004.12.017

Cowieson, A. J. (2010). Strategic selection of exogenous enzymes for corn/soy-based poultry diets. The Journal of Poultry Science, 47(1), 1-7. doi: 10.2141/ jpsa.009045

Cowieson, A. J., \& Ravindran, V. (2008). Effect of exogenous enzymes in maize-based diets varying in nutrient density for young broilers: growth 
performance and digestibility of energy, minerals and amino acids. British Poultry Science, 49(1), 3744. doi: 10.1080/00071660701812989

Dalólio, F. S., Moreira, J., Vaz, D. P., Albino, L. F. T., Valadares, L. R., Pires, A. V., \& Pinheiro, S. R. F. (2016). Exogenous enzymes in diets for broilers. Revista Brasileira de Saúde e Produção Animal, 17(2), 149-161. doi: 10.1590/S151999402016000200003

Dessimoni, G. V., Sakomura, N. K., Donato, D. C. Z., Soares, L., Sarcinelli, M. F., Malheiros, E. B., \& Dalólio, F. S. (2019). Growth performance and carcass yield of broiler chickens in response to carbohydrases and its association with phytase. Arquivo Brasileiro de Medicina Veterinária e Zootecnia, 71(3), 983-989. doi: 10.1590/1678-416210345

Fischer, G., Maier, J. C., Rutz, F., \& Bermudez, V. L. (2002). Desempenho de frangos de corte alimentados com dietas à base de milho e farelo de soja, com ou sem adição de enzimas. Revista Brasileira de Zootecnia, 31(1), 402-410. doi: 10.1590/S151635982002000200015

Fortes, B. D. A., Café, M. B., Stringhini, J. H., Brito, J. Á. G. D., Rezende, P. L. D. P., \& Silva, R. D. (2012). Avaliação de programas nutricionais com a utilização de carboidrases e fitase em rações de frangos de corte. Ciência Animal Brasileira, 13(1), 24-32. doi: 10.5216/cab.v13i1.8705

Francesch, M., \& Geraert, P. A. (2009). Enzyme complex containing carbohydrases and phytase improves growth performance and bone mineralization of broilers fed reduced nutrient corn-soybean-based diets. Poultry Science, 88(9), 1915-1924. doi: 10.3382/ps.2009-00073

Garcia, E. R. D. M., Murakami, A. E., Branco, A. F., Furlan, A. C., \& Moreira, I. (2000). Efeito da suplementação enzimática em rações com farelo de soja e soja integral extrusada sobre a digestibilidade de nutrientes, o fluxo de nutrientes na digesta ileal e o desempenho de frangos. Revista Brasileira de Zootecnia, 29(5), 1414-1426. doi: 10.1590/s151635982000000500020

González-Ortiz, G., Olukosi, O., \& Bedford, M. R. (2016). Evaluation of the effect of different wheats and xylanase supplementation on performance, nutrient and energy utilization in broiler chicks. Animal Nutrition, 2(3), 173-179. doi: 10.1016/j. aninu.2016.06.005Get
Gopinger, E., Krabbe, E. L., Surek, D., Lopes, L. D. S., \& Avila, V. S. (2017). Live performance, carcass, and bone quality responses of grower and finisher broilers to dietary metabolizable energy levels. Brazilian Journal of Poultry Science, 19(4), 559566. doi: 10.1590/1806-9061-2017-050

Kocher, A., Choct, M., Ross, G., Broz, J., \& Chung, T. K. (2003). Effects of enzyme combinations on apparent metabolizable energy of corn-soybean meal-based diets in broilers. The Journal of Applied Poultry Research, 12(3), 275-283. doi: 10.1093/ japr/12.3.275

Lei, X. J., Lee, J. S., Park, J. H., Lee, I. S., Ingale, S., \& Kim, I. H. (2017). Influence of exogenous multi-enzymes in broiler chickens fed on maizewheat-soybean meal-based diets. European Poultry Science, 81. doi: 10.1399/eps.2017.210

Leite, P. R. D. S. D., Leandro, N. S. M., Stringhini, J. H., Café, M. B., Gomes, N. A., \& Jardim, R. D. M., $F^{\circ}$. (2011). Desempenho de frangos de corte e digestibilidade de rações com sorgo ou milheto e complexo enzimático. Pesquisa Agropecuária Brasileira, 46(3), 280-286. doi: 10.1590/S0100204X2011000300 008

Liu, W. C., \& Kim, I. H. (2017). Effects of dietary xylanase supplementation on performance and functional digestive parameters in broilers fed wheat-based diets. Poultry Science, 96(3), 566-573. doi: $10.3382 / \mathrm{ps} /$ pew 258

Meneghetti, C. (2013). Associação de enzimas em rações para frangos de corte. Tese de doutorado em Zootecnia, Universidade Federal de Lavras. Lavras, MG, Brasil.

Meng, X., Slominski, B. A., Nyachoti, C. M., Campbell, L. D., \& Guenter, W. (2005). Degradation of cell wall polysaccharides by combinations of carbohydrase enzymes and their effect on nutrient utilization and broiler chicken performance. Poultry Science, 84(1), 37-47. doi: $10.1093 / \mathrm{ps} / 84.1 .37$

Moura, F. A. S., Dourado, L. R. B., Farias, L. A., Lopes, J. B., Lima, S. B. P., \& Fernandes, M. L. (2019). Complexos enzimáticos sobre a energia metabolizável e digestibilidade dos nutrientes do milheto para frangos de corte. Arquivo Brasileiro de Medicina Veterinária e Zootecnia, 71(3), 990-996. doi: 10.159 0/1678-4162-10021

Munyaka, P. M., Nandha, N. K., Kiarie, E., Nyachoti, C. M., \& Khafipour, E. (2016). Impact of combined $\beta$-glucanase and xylanase enzymes on growth performance, nutrients utilization and gut microbiota 
in broiler chickens fed corn or wheat-based diets. Poultry Science, 95(3), 528-540. doi: 10.3382/ps/ pev333

Noblet, J., Henry, Y., \& Dubois, S. (1987). Effect of protein and lysine levels in the diet on body gain composition and energy utilization in growing pigs. Journal of Animal Science, 65(3), 717-726. doi: 10. 2527/jas 1987.653717x

Oba, A., Lopes, P. C. F., Boiago, M. M., Silva, A. M. S., Montassier, H. J., \& Souza, P. A. D. (2012). Características produtivas e imunológicas de frangos de corte submetidos a dietas suplementadas com cromo, criados sob diferentes condições de ambiente. Revista Brasileira de Zootecnia, 41(5), 1186-1192. doi: 10.1590/S1516-35982012000500016

Olukosi, O. A., Cowieson, A. J., \& Adeola, O. (2008). Energy utilization and growth performance of broilers receiving diets supplemented with enzymes containing carbohydrase or phytase activity individually or in combination. British Journal of Nutrition, 99(3), 682-690. doi: 10.1017/ s0007114507815807

R Core Team (2019). R: A language and environment for statistical computing. Vienna, Austria: R Foundation for Statistical Computing. Retrieved from https:// www.R-project.org/

Rostagno, H. S., Albino, L. F. T., Donzele, J. L., Gomes, P. C., Oliveira, R. F., Lopes, D. C., \& Barreto, S. L. T. (2017). Tabelas brasileiras para aves e suínos; composição de alimentos e exigências nutricionais. Viçosa, MG: UF, Departamento de Zootecnia.

Roth, F. X., Gotterbarm, G. G., Windisch, W., \& Kirchgessner, M. (1999). Influence of dietary level of dispensable amino acids on nitrogen balance and whole-body protein turnover in growing pigs. Journal of Animal Physiology and Animal Nutrition (Germany), 81, 232-238.

Roth, F. X., Gotterbarm, G. G., Windisch, W., \& Kirchgessner, M. (1999). Influence of dietary level of dispensable amino acids on nitrogen balance and whole-body protein turnover in growing pigs. Journal of Animal Physiology and Animal Nutrition, 81, 232-238.

Sakomura, N. K., \& Rostagno, H. S. (2016). Métodos de pesquisa em nutrição de monogástricos (2a ed.). Jaboticabal: FUNEP.
Santos, T. T. dos, O’Neill, H. V. M., González-Ortiz, G., Camacho-Fernández, D., \& López-Coello, C. (2017). Xylanase, protease and superdosing phytase interactions in broiler performance, carcass yield and digesta transit time. Animal Nutrition, 3(2), 121-126. doi: 10.1016/j.aninu.2017.02.001

Silva, D. M. da, Rodrigues, D. R., Gouveia, A. B. V. S., Mesquita, S. A., Santos, F. R. dos, \& Minafra, C. S. (2016). Carboidrases em rações de frangos de corte. PUBVET, 10(11), 795-872. doi: 10.22256/pubvet. v10n11.861-872

Statistical Analysis System Institute (2009). Using JMP student edition for Windows and Macintosh: the user's guide to statistics with JMP student edition. Cary: SAS institute.

Souza, R. M. D., Bertechini, A. G., Sousa, R. V. D., Rodrigues, P. B., Carvalho, J. C. C. D., \& Brito, J. Á. G. D. (2008). Efeitos da suplementação enzimática e da forma física da ração sobre o desempenho e as características de carcaça de frangos de corte. Ciência e Agrotecnologia, 32(2), 584-590. doi: 10.1590/ S1413-7054200800020003

Temim, S., Chagneau, A. M., Guillaumin, S., Michel, J., Peresson, R., \& Tesseraud, S. (2000). Does excess dietary protein improve growth performance and carcass characteristics in heat-exposed chickens? Poultry Science, 79(3), 312-317. doi: 10.1093/ ps/79.3.312

West, M. L., Corzo, A., DozierIii, W. A., Blair, M. E., \& Kidd, M. T. (2007). Assessment of dietary Rovabio Excel in practical United States broiler diets. Journal of Applied Poultry Research, 16(3), 313-321. doi: 10.1093/japr/16.3.313

Woyengo, T. A., \& Nyachoti, C. M. (2011). Review: supplementation of phytase and carbohydrases to diets for poultry. Canadian Journal of Animal Science, 91(2), 177-192. doi: 10.4141/cjas10081

Zanella, I., Sakomura, N., Silversides, F., Fiqueirdo, A., \& Pack, M. (1999). Effect of enzyme supplementation of broiler diets based on corn and soybeans. Poultry Science, 78(4), 561-568. doi: 10. 1093/ps/78.4.561 
